\title{
ANNUAL MEETING, 1943, TO BE HELD IN TORONTO
}

In June the various members of the General Executive were asked to indicate where, in their opinion, the 1943 Annual Meeting should be held. The views of the Sections were also canvassed through the Section Representatives. The concensus of opinion favoured Toronto, with Winnipeg a close second. Toronto and Montreal were equally favoured second choices. The President has, therefore, announced that the Annual Meeting will be held in Toronto either immediately preceding or immediately following the Annual Meeting of the Woodlands Section of the Canadian Pulp and Paper Association. The date of the meeting will be announced in the December issue of the Chronicle.

\section{NEWS OF THE SECTIONS}

\section{MARITIMES}

The sixth summer meeting of the Maritime Section was held at Fredericton on June 29 and 30 . In addition to the regular business meetings a talk on the A.R.P. work in New Brunswick by Dr. J. M. Gibson and a dinner held at the Acadian Forest Experiment Station were enjoyed by the members and their guests.

A paper read by Mr. R. S. Johnson on "A Forest Policy for Nova Scotia" and a discussion led by $M r$. G. W. I. Creighton on "An Act relating to the Conservation of Small Trees" were the main topics brought up at the meeting.

The Act relating to the Conservation of Small Trees was recently passed in Nova Scotia, and it promoted considerable interest at the meeting. Most of the members considered the Act was a step in the direction of better management of private lands as it would permit regulations preventing the cutting of immature timber. There was some lively discussion, however, about the details of the Act. It was pointed out that the success of such an Act would depend on the nature of the regulations drawn up under it and the personnel available for administering it. Some objection was expressed to the limitation to holdings of over 1,000 acres as a large proportion of the forest products of the province come from smaller holdings. This might reduce the effectiveness of the Act and increase overcutting on smaller holdings. On the other hand practical considerations were held to force this limitation at the present time and if the Act could be shown to be an effective agent in producing better cutting methods this would lead to downward revision of the size of holdings to which it applied. A committee was appointed to study the Act and consider regulations which would make it effective. It was thought that this legislation was important as a first attempt to improve cutting on private lands by regulation and that its administration was a matter of great interest to foresters.

W. W. MacCormack, K. B. Brown, W. A. Reeks and R. F. Morris spent two weeks during July at Reserve Army Training camps at Woodstock and Tracadie, N.B.

A daughter was born to Mr. and Mrs. G. W. I. Creighton of Halifax on May 5. 